\title{
Perception of Mothers regarding their Neonatal Hyperbilirubinemia
}

\author{
Samer Mohamed Tawfik ${ }^{1}$, Mona Ahmed El Shikh ${ }^{2}$, Eman Mohamed Abd El-Hakam ${ }^{3}$ and \\ Ola Abdel-Wahab Afifi ${ }^{4}$
}

(1) Nurse Specialist in Al-Shouhada Central Hospital, (2) Professor of Obstetrics \& Gynecological Nursing- Faculty of Nursing- Ain Shams University - Egypt, (3) Assist. Prof. of Obstetric and woman's Health Nursing - Faculty of Nursing- Benha University - Egypt, (4) Lecturer of Obstetric and woman's Health Nursing- Faculty of Nursing-Benha University Egypt.

\section{Abstract:}

Background: Worldwide, neonatal hyperbilirubinemia is a common neonatal disorder. Aim: The study aimed to assess perception of mothers regarding their neonatal hyperbilirubinemia. Research design: Descriptive study design was utilized to conduct the study. Setting: The study was conducted in Neonatal Follow-up Clinics and Immunization Clinics at Benha University Hospitals, Family Health Care Center and Central Hospital in Al-Shouhada City. Sample: A purposive sample was used to conduct the study, included (300) mothers who fulfill the inclusive criteria. Tools: There were four tools used in the study. Tool (I): Structured interviewing questionnaire that includes socio-demographic data and current obstetrics history. Tools(II): Assessment of mother's knowledge regarding neonatal hyperbilirubinemia. Tools (III): Self_report practices regarding neonatal hyperbilirubinemia and tool (IV): Modified Likert Scale to assess attitude of mothers regarding neonatal hyperbilirubinemia. Results: Less than three-quarters of the studied women had poor knowledge regarding neonatal hyperbilirubinemia, majority of mothers had unsatisfactory self-report practices and minority of them had satisfactory self-report practices. About two-thirds the studied women had negative attitude regarding neonatal hyperbilirubinemia . Conclusion: The studied women had poor knowledge and negative attitude regarding neonatal hyperbilrubinemia especially among primipara. Regarding self_report practices of mothers, majority of mothers had unsatisfactory self-report practices and minority of them had satisfactory self-report practices Recommendedations: Targeted public enlightenment and educational program should be done to improve the level of awareness regarding neonatal hyperbilirubinemia.

Key words: Mothers, Neonatal Hyperbilirubinemia, Perception.

\section{Introduction:}

Neonatal period define as the time of birth up to 28th day of life. Neonatal period is the most critical time for the survival of an infant. Approximately $60 \%$ of term and $80 \%$ of preterm newborns during the first week suffered from most common and important conditions needing medical attention in neonates called neonatal hyperbilirubinemia and about $10 \%$ of breastfed babies are still jaundiced at 1 month (Erlichman and Loomes, 2019).

Neonatal hyperbilirubinemia is yellowish discoloration of eyes and skin as result of an increase in total serum bilirubin level. Bilirubin formed when the body breaks down old red blood cells. The liver usually processes and removes the bilirubin from the blood. Jaundice in babies usually occurs because of a normal 
increase in red blood cell breakdown and the fact that their immature livers are not efficient at removing bilirubin from the bloodstream (Blair , 2018).

Therefore, the baby's liver plays the most important part in bilirubin breakdown. The type of bilirubin that causes the yellow discoloration of jaundice is called unconjugated or indirect bilirubin. This form of bilirubin is not easily removed from the baby's body. The baby's liver changes this unconjugated bilirubin into conjugated or direct bilirubin, which is easier to excrete. The liver of a newborn baby is immature, so the job of conjugating and removing bilirubin is not done completely well (Bhattacharyya, 2017).

The nurses play pivotal role in equipping the mother by knowledge about neonatal hyperbilirubinemia and positively change their attitude (Wells, 2018). Increasing, the nurses are the key stone in caring and monitoring hospitalized babies with jaundice during phototherapy, exchange transfusion and intravenous immunoglobin (Bhandari, 2020). Mothers play a very important role in final results of jaundice after discharging the babies from hospital (Mendoza, 2016). Therefore, the nurse should ascertain the knowledge level of the mothers about NNJ and the care offered by them to their babies.

\section{Significance of the study}

Neonatal Jaundice (NNJ) is a transitional phenomenon affecting most newborns with largely benign consequences in the first week of life. Worldwide, incidence of (NNJ) considers $55 \%$ of term babies and up to $75 \%$ of preterm babies (Goodman, et al, 2016). Incidence of neonatal jaundice in Egypt is present in $60 \%$ of term babies and up to $80 \%$ of premature babies (Slusher, et al, 2015).
Neonatal jaundice leads to serious complication that affect newborn such as acute bilirubin encephalopathy and kernicterus. And also consider a major contributing cause for cerebral palsy in Egyptian infants. Kernicterus was the third most common cause of developmental delay in Egyptian's newborn composing 9\% of the whole etiologies (Mostafa, et al, 2019). In Cairo University Children's Hospital, severe neonatal hyperbilirubinaemia accounted for $33 \%$ of total admission diagnoses to the out born Neonatal Intensive Care Unit (NICU) in 2016 with about 10 cases of kernicterus occurring each year (Bosschaart et al, 2016). Therefore, the aim of this study was to assess perceptions of mothers related to neonatal hyperbilirubinemia.

\section{Aim of the study:}

The aim of the present study was to assess perception of mothers regarding neonatal hyperbilirubinemia.

\section{Research question:}

- What is the level of mother's knowledge regarding neonatal hyperbilirubinemia?

- What about mother's self-report practices regarding neonatal hyperbilirubinemia?

- What is the mother's attitude toward neonatal hyperbilirubinemia?

\section{Subjects and Method:}

\section{Research Design:}

A quasi- experimental design was used to fulfill this study.

\section{Research setting:}

This study was conducted in neonatal follow-up clinics and immunization clinics at Benha University Hospital (165 mother), family health care center in Al-Shouhada 
city(20 mother) and central hospital at AlShouhada (115 mother). The family health center and central hospital in Al-Shouhada were added to study setting to compelet the predetermined sample size, because Benha University Hospital is transformed to isolation hospital due to breakout covid-19.

\section{Sampling:}

Sample type: A purposive sample was used.

\section{Sample size:}

The total number of mothers at neonatal follow-up clinics and immunization clinics at Benha University Hospital at (2019) was 4055 mothers (Benha University Hospital Census Report, 2019). The sample size as calculated by the following formula was (300) mothers

$$
\begin{aligned}
& n=\frac{N}{1+N(e)^{2}} \\
& \mathrm{n}=\text { sample. } \\
& \mathrm{N}=\text { population } \\
& \mathrm{e}=\text { margin error }(.05) . \\
& \text { Inclusion criteria: }
\end{aligned}
$$

- Different age of mothers.

- Different parity.

- Normal delivery.

- Normal newborn.

- Willing to participate in the study.

\section{Exclusion criteria:}

- Mothers who had mental disorders.

- Abnormal labor.

- Mothers who refused to participate in the study.

\section{Tools of data collection:}

Three tools were used for collecting data.

The following four tools were designed after reviewing related literature and under supervision of the supervisors of the study.

\section{Tools I: Structured interviewing questionnaire: that includes two parts:}

Part (1): Personal characteristics of studied women such as (age, level of education, occupation, residence).

Part (2): Current obstetrics history as (number of pregnancy, number of labour, current gestational age, type of last delivery, previous history of a newborn baby suffering from jaundice, presence of complications in last pregnancy and preterm labour)

$\begin{array}{llll}\text { Tools II: Assessment of } & \text { mother's } \\ \text { knowledge } & \text { regarding } & & \text { neonatal } \\ \text { hyperbilirubinemia: } & & \end{array}$

This sheet includes 25 questions. Scoring system:

All knowledge variables were weighted according to items included in each question. The answers of the question were classified into 2 categories. The answers would have score (1) for correct answer and (0) for incorrect answer or don't know.

Total knowledge score was converted into percentage and classified as the following:

Good: ( $\geq 75 \%$ correct answers).

Average: (60 - < $75 \%$ correct answers) Poor: $\quad(<60 \%$ correct answers).

Tools (III): Mother's self-report in relation to their practice regarding their neonates with hyperbilirubinemia, such as: It included 12 items.

\section{Scoring system:}

All self-report practices variables were weighted according to items included in each statement. The practices were classified into 2 categories (1) score for correct practices and (0) score for incorrect practices.

Total self-report practices score was (12) and classified as the following: 
Satisfactory self-report practice $(\geq 10 \%$ correct answers).

Unsatisfactory self-report practice $(<10 \%$ correct answers).

\section{Tool IV. Modified Likert Scale:}

It was adopted from (Moawad, 2016) and modified by the researcher and the guidance of the supervisors of the study to have broader study about mother's attitude. The scale was implemented by the researcher to assess attitude of the studied mothers as regarding neonatal hyperbilirubinemia. The scale was consisted of (13) statement from three -point (likert scale type) about several issues constructed to measure attitude of studied mothers regarding neonatal hyperbilirubinemia.

\section{Scoring system:}

To obtain the outcome of attitude scale, each statement scored as following; (2) if the response was "agree", (1) if it was 'some times', and (zero) if it was"disagree" .The total score is expressed as apercentage.

Total attitude score was converted into percentage and classified into:

Highly positive attitude: $>75 \%$

Positive attitude: $60 \%<75 \%$

Negative attitude: $\quad 75<60 \%$

\section{Ethical consideration:}

Each studied woman was given explanations about the purpose of the study and informed that participation was voluntary. They have free to withdraw from the study at any time before the completion of it. The woman who was agreeing to complete in this study was asked to sign consent from before starting the data collection. Confidentiality was ensured throughout the study process and the women were assured that all data was used only for study purpose.

\section{Tools validity:}

Tools were developed by the researcher after the review of literature. The tool was tested for its content validity by panels of three experts in the field of Obstetrics and woman's health nursing and pediatric medicine at Faculty of Benha University to test content validity.

\section{Tools reliability:}

The reliability was done by cronbach's Alpha coefficient test which revealed that each of the tools consisted of relatively homogenous items as indicated by the moderate to high reliability of tools. Cronbach's Alpha of knowledge was (.76).

\section{Pilot study:}

A pilot study was carried out on $10 \%$ of total sample size which was (30) women. It was conducted to test the simplicity, clarity and applicability of the developed tools, also to find out the possible obstacles and problems that maight face the researchers and interfere with data collection, and to estimate the time needed for data collection. According to the results of pilot study, required modifications were done. The women involved in the pilot were be excluded from the study

\section{Field work:}

- Data were collected through a period of six months from the begning of March 2020 to the end of August 2020 in neonatal follow-up clinic and immunization clinic at Benha University Hospitals, to select mothers that their babies have hyperbiliruninemia.

- $\quad$ The researcher visited the previously mentioned study settings 2 days/week from 9 am to $2 \mathrm{pm}$ ( Mondays and Thursdays).The researcher started to collect data from Banha University Hospital from beginning of March to the end of April because Banha University 


\section{Perception of Mothers regarding their Neonatal Hyperbilirubinemia}

Hospital was transformed into isolation hospital. So, the researcher had to seek help from other places to complete the sample collection, these places were Family Health Center and Central Hospital at El-Shouhada City. The collection took place from the beginning of May to the end of August.

- The researcher met (4-6 women/day). The researcher introduced herself, greet women, the purpose of study was explained by the researcher and oral consent was taken to participate in study.

- The researcher interviewed the mothers to collect personal characteristics of study sample.

- The researcher introduced structured interviewing questionnaires to the studied sample (Tool II) to assess personal characteristics of study sample \& current obstetric data. This tool takes about 10-15 minutes to fulfill.

- Then, the researcher continued interviewing the mothers to fulfill (Tool II, III) which assess the mother's knowledge and selfreport regarding neonatal hyperbilirubinemia.

- The time required to fulfill (Tool II, III) was 15-20 minutes.

- Finally, the mother's attitude regarding (NHB) was assessed through (Tool IV). The time required to fulfill (Tool IV) was 15 minutes

- The previously mentioned steps were repeated for each mother until the previously mentioned sample size completed.

\section{Statistical analysis:}

- Data were verified prior to computerized entry. The statistical package for social sciences (SPSS version 20) was used for that purpose, followed by data tabulation and analysis. Descriptive statistics were applied (e.g., mean, standard, deviation, frequency and percentage). Test of significance (t-test, chisqure).A significant level value was considered when $\mathrm{p} \leq 0.05$. In addition, a highly significant level value was considered when $\mathrm{p}<0.01$.

\section{Results}

Table (1): Shows the personal characteristics data of the studied women, it was cleared that more than half $(58.7 \%)$ of the studied sample was in the age group of 18-24 years with a mean age of $22.81 \pm 6.90$ years. Also, about two-thirds $(61.7 \%)$ of women lived in rural areas. Regarding educational level, about half of them $(49.7 \%)$ had secondary education. In addition; regarding occupation, more than two-thirds (69.3\%) of them were housewife.

Table (2): Illustrates that, more than half of the studied sample $(54.7 \%)$ was primigravida. Furthermore, less than twothirds of them $(60.0 \%)$ were primipara. As regards the current gestational age, the mean gestational age of them was $38.72 \pm 1.43$ weeks. Also, minority of them $(8.0 \%)$ had preterm labour and less than two thirds of them $(62.7 \%)$ delivered by C.S.

Figure (1): Shows that $62.3 \%$ of studied women's had poor total knowledge regarding neonatal hyperbilirubinemia.

Table (3): Illustrates that the majority of mothers $(76.3 \%)$ had unsatisfactory selfreport practices and minority of them (23.7) had satisfactory self-report practices.

Figure (2): Shows that $66.0 \%$ of studied women's had poor total attitude regarding neonatal hyperbilirubinemia. 
Table (1): Personal characteristics of the studied women $(n=300)$.

\begin{tabular}{|c|c|c|}
\hline Personal characteristics & No & $\%$ \\
\hline \multicolumn{3}{|l|}{ Age in (years) } \\
\hline $18-$ & 176 & 58.7 \\
\hline $25-$ & 62 & 20.7 \\
\hline $30-$ & 31 & 10.3 \\
\hline$\geq 35$ & 31 & 10.3 \\
\hline \multicolumn{3}{|l|}{ Mean \pm SD $=22.81 \pm 6.90$} \\
\hline \multicolumn{3}{|l|}{ Residence: } \\
\hline Rural & 185 & 61.7 \\
\hline Urban & 115 & 38.3 \\
\hline \multicolumn{3}{|l|}{ Level of Education } \\
\hline Read \& write & 21 & 7.0 \\
\hline Basic education & 36 & 12.0 \\
\hline Secondary education & 149 & 49.7 \\
\hline University education & 94 & 31.3 \\
\hline \multicolumn{3}{|l|}{ Occupation } \\
\hline Housewife & 208 & 69.3 \\
\hline Employer & 92 & 30.7 \\
\hline
\end{tabular}

* Results not mutually exclusive

Table (2): Distribution of the studied women according to their current obstetrical history $(\mathbf{n}=\mathbf{3 0 0})$.

\begin{tabular}{|c|c|c|}
\hline Obstetrical data & No & $\%$ \\
\hline \multicolumn{3}{|l|}{ Number of pregnancy } \\
\hline Primigravida & 164 & 54.7 \\
\hline Multigravida & 136 & 45.3 \\
\hline \multicolumn{3}{|l|}{ Number of parity } \\
\hline Primipara & 180 & 60.0 \\
\hline Multipara & 120 & 40.0 \\
\hline \multicolumn{3}{|l|}{ Mean \pm SD = $38.72 \pm 1.43$} \\
\hline \multicolumn{3}{|l|}{ Current gestational age: } \\
\hline Preterm & 24 & 8.0 \\
\hline Full-term & 276 & 92.3 \\
\hline \multicolumn{3}{|l|}{ Type of last delivery } \\
\hline Vaginal delivery with episiotomy & 112 & 37.3 \\
\hline C.S & 188 & 62.7 \\
\hline $\begin{array}{l}\text { Previous history of a newborn baby suffering from jaundice } \\
(n=120)\end{array}$ & 34 & 28.3 \\
\hline Presence of complications in last pregnancy & 108 & 36.0 \\
\hline
\end{tabular}

* Results not mutually exclusive 


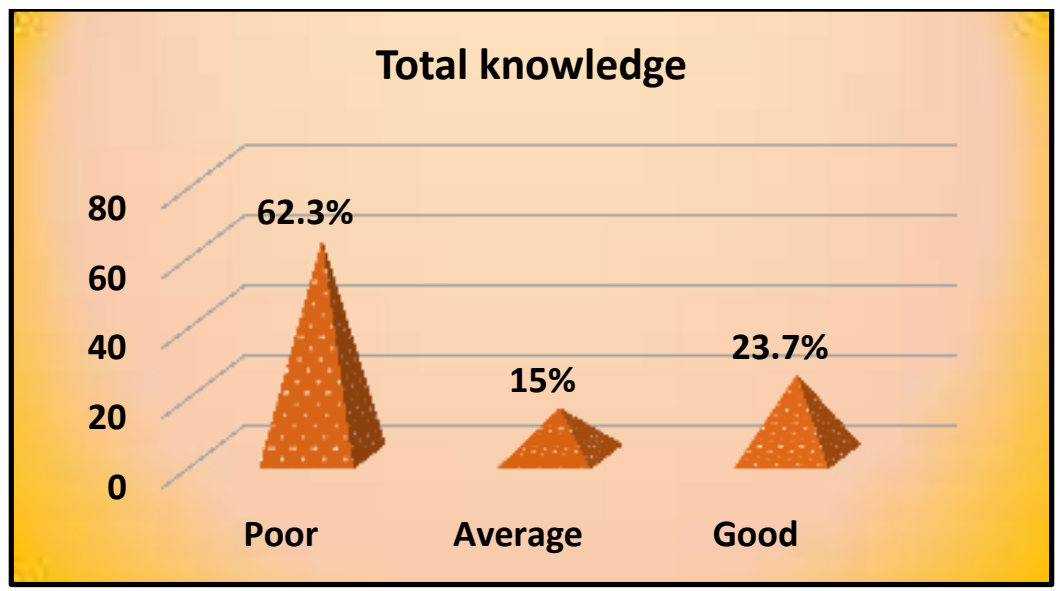

Figure (2): Distribution of studied women's total knowledge regarding neonatal hyperbilirubinemia $(\mathrm{N}=\mathbf{3 0 0})$.

Table (3): Percentage distribution of studied women's total self_report practices regarding dealing with neonatal hyperbilirubinemia $(\mathrm{N}=300)$.

\begin{tabular}{|l|l|l|}
\hline Total self-report practices & No & \% \\
\hline Satisfactory self-report practices & 71 & 23.7 \\
\hline Unsatisfactory self-report practices & 229 & 76.3 \\
\hline
\end{tabular}

\section{total attitude}

$10.7 \%$

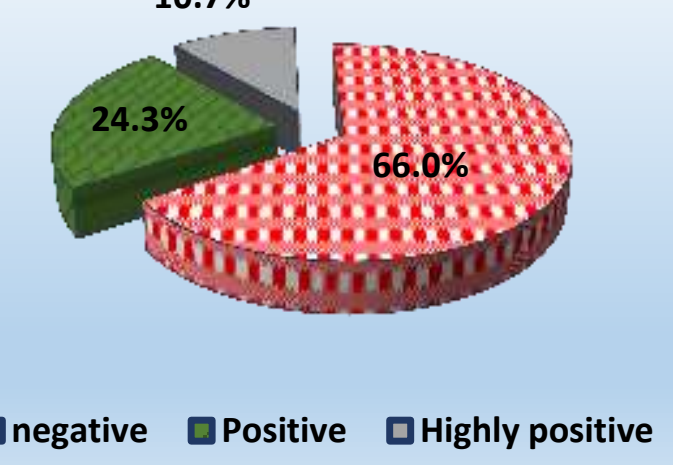

Figure (3): Distribution of studied women's total attitude regarding neonatal hyperbilirubinemia $(\mathbf{N}=300)$. 


\section{Discussion}

Neonatal hyperbilirubinemia is a common condition in newborn infant, result from an elevated level of bilirubin in the blood, characterized by yellowish discoloration of the skin, mucous membranes and the eyes. Worldwide, neonatal hyperbilirubinemia is occurring in up to $60 \%$ of term and $80 \%$ of preterm newborns in the first week of life. Newborns show clinical signs which tend to start on the head and face and then spread down the trunk and limbs as a result of high serum levels of bilirubin (Nassar, et al, 2015). Increasingly, in Egypt the incidence of NNJ 55\% of term infant and $75 \%$ of preterm infant (Haque and Rahman, 2018). The current study aimed to assess perception of mothers regarding their neonatal hyperbilirubinemia. This aim was significantly achieved through descriptive research design.

\section{Personal characteristics of studied} women such as age, residence, occupation and educational level mainly affect women's knowledge and attitude regarding neonatal hyperbilirubinemia. So, these factors should be determined for the studied sample. The finding of the current study revealed that more than half of the studied sample was in the age group of 18-24 years with a mean age of 22.81 \pm 6.90 years. Also, about two-thirds of women lived in rural areas. Regarding educational level, about half of them had secondary education. In addition; regarding occupation, more than two-thirds of them were housewife.

This result was in accordance with Maisels (2016) who studied "Home Practices of Kurdish Mothers Regarding Management of Jaundice among Newborns in Erbil City", showed that the highest percentage of them was $(81.5 \%)$ among $23-35$ years. Regarding the mother's occupation, the majority of mother's were unemployed, which presents $(83.1 \%)$ and in respect to residential area, most of mother's were from suburban areas. This similarity in results might be related to the similarities of community features. On the other hand, Maisels (2016) cleared that the level of mother's education, the highest percentage was primary education $(41.5 \%)$.

In addition, the results of the present study came nearly in the same line with Olusanya et al (2016) who studied "Assessment of Mothers' Knowledge and Beliefs toward Care of Neonatal Jaundice in Pediatric Teaching Hospital in Holy Karbala City" cleared that the most of mothers $(42.3 \%)$ within age group (26-30) years old, (80\%) of the mothers in current study were housewife and most of the mothers $(30.2 \%)$ were housewife. On the other hand, Olusanya et al (2016) indicated that the most of the mothers $(65 \%)$ living in urban areas.

In contrast to the results of present study, Daniel, et al (2017) who conducted "Knowledge Regarding Neonatal Jaundice Management among Mothers: A Descriptive Study Done In a Tertiary Level Hospital of Dhaka City", showed that $64 \%$ of the mothers completed primary level of education.

As regards obstetric history, the current study finding revealed that more than half of the studied sample was primigravida. Furthermore, less than two-thirds of them was primipara. As regards the current gestational age, the mean gestational age of them was $38.72 \pm 1.43$ weeks. Also, minority of them had preterm labour and less than two thirds of them delivered by C.S. regarding complications in last pregnancy.

The results of present study agreed with Shrestha, et al (2019) who studied "Knowledge about Neonatal Jaundice among Nepalese Mothers", showed that more than half of the mothers $(55 \%)$ were primiparous. 
In contrast to the results of present study Olusanya and Slusher (2019) who studied "Neonatal Jaundice: awareness, perception and preventive practices in expectant Mothers", illustrated that only $(36.0 \%)$ were nulliparous.

Knowledge is a familiarity, awareness, or understanding of someone or something, such as facts (propositional knowledge), skills (procedural knowledge), or objects (acquaintance knowledge). By most accounts, knowledge can be acquired in many different ways and from many difference sources, including but not limited to perception, reason, memory, scientific inquiry, education, and practice (Maisles,2016). So, the mothers should understand all knowledge associated with neonatal jaundice and the complications that might occur to the baby.

The finding of this study illustrated that, less than three-quarters of the studied women had poor knowledge regarding neonatal hyperbilirubinemia, while one quarter of them had good knowledge.

The results of current study agreed with Stockman, (2016) who studied "Mothers' perception of neonatal jaundice in Lagos, Nigeria: An urgent need for greater awareness", demonstrated that majority of mothers had poor knowledge about neonatal hyperbilirubinemia.

The results of current study matched with Allahony, et al. (2016) who studied "Mothers' perception of neonatal jaundice in Jazan Region, KSA", showed that there was poor level of knowledge about neonatal jaundice among mothers, whereas $60.4 \%$ had poor knowledge and only $39.6 \%$ had good knowledge. This similarity in results because most of mothers not attending educational courses or workshop.
In addition to this, Ogunlesi and Abdul (2015) who studied "Neonatal Jaundice: Knowledge, Attitude and practices of mothers in Mosan-Okunola community, Lagos, Nigeria", showed that up to $70 \%$ of the mothers had poor knowledge.

The result of current study disagree with Boo et al. (2016) who studied "Mothers' perception toward neonatal jaundice in Kafr El-batanoon village, Menoufia, Egypt", indicated that an overall $74 \%$ of mothers had good knowledge. These differnces maight be due to difference level of education and available technology.

Regarding to total self-report practices of mothers to their newborns with hyperbilirubinemia, the finding of this study illustrated that majority of mothers $(76.3 \%)$ had unsatisfactory self-report practices and minority of them $(23.7 \%)$ had satisfactory self-report practices.

The results of present study agreed with Rodrigo and Cooray, (2015) who studied "the knowledge, attitude \& behaviour on neonatal jaundice of postnatal mothers in Provincial General Hospital, Badulla", showed that majority (about 90\%, $\mathrm{n}=345$ ) of mothers had unsatisfactory self-report practices for neonatal jaundice.

Attitude is emotional, motivational, perceptive and cognitive beliefs that positively or negatively influence the behavior or practice of an individual. Pertaining to the studied sample's attitude regarding neonatal jaundice, the results of present study showed that about two-thirds the studied women had negative attitude regarding neonatal hyperbilirubinemia, and minority of them had positive attitude

The results of current study were in consistence with Rodrigo and Cooray 
(2015), showed that majority of mothers had poor level of attitude about NNJ. On the opposite to finding of present study Rodrigo and Cooray (2015), showed that about (55\%) of mothers had a high level of attitude about neonatal jaundice.

\section{Conclusion}

Less than three-quarters of the studied women had poor knowledge regarding neonatal hyperbilirubinemia, while less than one-quarter of them had good knowledge. Regarding to self- report practices of mothers, majority of mothers had unsatisfactory selfreport practices and minority of them had satisfactory self-report practices. Regarding total attitude, about two-thirds the studied women had negative attitude regarding neonatal hyperbilirubinemia, and minority of them had positive attitude. Moreover, there was a highly statistically significant relation between total knowledge scores, total attitude regarding neonatal hyperbilirubinemia and educational level and residence. Additionally, there was a highly statistically significant relation between total knowledge scores, total attitude regarding neonatal hyperbilirubinemia and parity of the studied women ( $\mathrm{p} \leq 0.001)$.Also, there was a highly statistically significant relation between total self-report practices scores regarding neonatal hyperbilirubinemia and educational level. Also, there was a highly statistically significant positive correlation between total knowledge scores and total attitude scores regarding neonatal hyperbilirubinemia $(\mathrm{p} \leq$ 0.001). Finally, the finding of the current study were answered the study questions and achieved the aim of the study.

\section{Recommendations}

- Targeted public enlightenment and educational program should be done to mothers to improve the level of awareness regarding neonatal hyperbilirubinemia.

- Health education topics during antenatal visits must include NNJ using colored posters, booklets and brochures to enhance women's perception regarding neonatal hyperbilirubinemia.

\section{Further study need to be performed:}

- Comparative study that can be conducted to evaluate mothers' awareness between urban and rural areas.

- Integrating neonatal hyperbilirubinemia in curriculum of nursing students.

\section{Acknowledgment}

The authors would like to express their appreciation and gratitude to all participants in the study.

\section{References}

Allahony D, Hegazy $N$, Kasemy $Z$ and Bahgat E (2016).Mother's perception toward Neonatal Jaundice in Kafr El-batanoon Village, Menofia, Egypt, Menofia Medical Journal, 29(3):743-748.

Bhandari, (2020).Neonatal Jaundice: causes and signs of Kernicturs that occurs to newborn. Pediatrics, 23(8) 234-239.

Bhattacharyya N, (2017). Auditory brainstem response audiometry. pediatrics,88(54)145-77.

Blair E,2018. Epidemiology of the cerebral palsies. Orthopedic Clinics of North America. 41(55):441-455.

Boo N, Gan C, Gian Y, Lim K, Lim M, Kumar H (2016). Malaysian mothers' knowledge and practices on care of neonatal jaundice. Med J Malaysia 66(88) 239-243. 
Bosschaart N, Kok JH, Newsum AM, Ouwenee DM, Mentink R, van Leeuwen TG, (2016). Limitations and opportunities of transcutaneous bilirubin measurement. Pediatrics, 129(66): 689-697.

\section{Daniel, Olusoga B, Ogunfowora, Olusoji J (2017).Neonatal jaundice and its} management: knowledge, attitude and practice of communityhealth workers in Nigeria. BMC Public Health,56(9) 6:19.

Erlichman and Loomes, (2019) . Causes of cholestasis in neonates and young infants, pediatrice,786(88) 132-44.

\section{Goodman K, Roser M, Rolinski B, Kadow} I, Muller C, Goerlach-Graw A, et al. (2015). Bilirubin measurement for neonates: Comparison of 9 frequently used methods. Pediatrics, 117 (4): 1174-83.

Haque and Rahman,(2018). An unusual case of $\mathrm{ABO}$-haemolytic disease of newborn. American Journal of nursing Research, 26 (2): 61-64.

Maisels MJ,(2016).Managing the jaundiced newborn;Persistent Challenge.Canadian Medical Association Journal,30(9)187-335

Mendoza AO,(2016). Jaundice. In: MacDonald MG, Mullett MD, Seshia MMK eds. Avery's neonatology. 6th ed. Philadelphia: Lippincott Williams \& Wilkins. 43(67) 789-9.

Moawad ,(2016). Complication of neonatal jaundice ,Menofia Medical Journal,19(5):3695

Mostafa, M. A., Kamal, N. M., Eltaher, S., Hamed, Y., Abdelaziz, H., Abdelghany, W. and Sherief, L. M. (2019). Knowledge of neonatal hyperbilirubinemia among primary health care physicians: a single-center experience. Clinical Medicine Insights: Pediatrics, 13, 1179556518824375.

Nassar, Lain, C.L. Roberts, J.R. Bowen, (2015). Early discharge of infants and risk of readmission for jaundice.Pediatrics, 135 (22)314-321.

Ogunlesi and Abdul (2015). Maternal knowledge and care-seeking behaviors for newborn jaundice in Sagamu, Southwest Nigeria. Niger J Clin Pract, 18(22)33-40

Olusanya and Slusher (2019). Infants at risk of significant hyperbilirubinemia in poorlyresourced countries:evidence from a scoping review. World J Pediatrics, 11(4):293-299

Olusanya BO, Osibanjo FB, Slusher TM. (2016). Risk factors for severe neonatal hyperbilirubinemia in low and middle-income countries: a systematic review and metaanalysis. PLoS One, 10 (2): 117-229.

Rodrigo B, Cooray G (2015). The knowledge, attitude \& behavior on neonatal jaundice of postnatal mothers in Provincial General Hospital, Badulla. Sri Lanka Journal of Child Health, 40(4): 164-168.

Shrestha S , Adachi K, Petrini MA, ShresthaS(2019).Knowledge about Neonatal Jaundice among NepaleseMothers. JBPKIHS2, 45(1): 34-42.

Stockman JA. (2016). Overview of the state of the art of Rh disease: history, current clinical management, and recent progress. J Pediatr Hematol Oncol, 23( 8): 554-562.

Slusher TM, Olusanya BO, Hendrik J, (2015). A randomized trial of phototherapy with filtered sunlight in African neonates. NEJM, 373(12), 1115-1124.

Wells, 2018. Strategies for neonatal hyperbilirubinaemia: A literature review. The American Journal of Maternal and Child Nursing 38(6):377-382. 
إدراك الأمهات فيما يتعلى بارتفاع مستوى بيليروبين الام عند الأطفال حديثى الولاده

$$
\text { سمر تحمد توفيق- منى أحمد الثيخ-ايمان حمح عبدالحكم- علا عبدالو هاب عفيفى }
$$

يعتبر إرتفاع بيليروبين الدم عند الأطفال مشكلة شائعة خلال فترة حديثي الولادة.ويعرف اليرقان الوليدي بانه تغير لون الجلد ولون الجبين إلى اللون الأصفر عند حديثي الولادة بسبب ارتفاع مستوى البيليروبين في الدم علي مستوي العالم ، يصاب ما بين 60٪ إلى 80٪ من الأطفال الأصحاء باليرقان الوليدي مجهول السبب .هناك نوعان شائعان من إرتفاع بيليروبين عند حديثي الولادة وهما اليرقان المرضي و الفسيولوجى و اللذين بسببان اليرقان الدماغي الحاد و البيليروبين إذا لم يتم علاجهما مبكرًا. ولذا هدفت هذه الدر اسة إلى تقييم إدر الك الأمهات فيما يتعلق بإرتفاع مستوى بيليروبين الدم عند الأطفال حديثى الولاده .وأجريت هذه الدراسة في عيادات متابعة حديثي الولادة وعيادات التطعيم بمستشفى بنها الجامعي ومركز رعاية الأمومة والطفولة بمدينة الثهداء و المستشفى المركزي بمدينة بالثهداء وبلغت العينة الكلية (300)أم تم اختيار هم من خلال العينة الهادفة.كما أوصت الدر اسة على انه ينبخي تطبيق البرامج التعليمية لتحسين مستوى الوعي بشأن إرتفاع بيليروبين الدم عند الأطفال حديثي الو لادة ويجب دعم العيادات الخارجية لمتابعة الحمل وزيارات ما بعد الولادة بصور ملونة وكتيب وبروشورات توضيحية لتعزيز تصور المرأة فيما يتعلق بارتفاع بيليروبين الدم عند الأطفال حديثي الو لادة. 